\title{
PHYTO-GEOGRAPHY OF NEPAL HIMALAYA
}

\author{
Devendra M. Bajracharya
}

\section{INTRODUCTION}

The Himalaya chain consists of a complex system of nearly parellel range of tertiary mountains, which is about 40 million years old and is the youngest mountain in the world. It stretches over nearly $3,000 \mathrm{Km}$. almost from the border of Afghanistan in the West to the North of Burma in the East. The Himalayas are usually divided into four geographical divisions: 1.Assam Himalaya, 2.Nepal Himalaya, 3.Kumaon-Garhwal Himalaya 4.Punjab- Kashmir Himalaya. The Nepal Himalaya is about $900 \mathrm{Km}$. long from the River Kali in the west to the Tista river in the east (Mani; 1984:85). It is roughly a rectangular piece of land occupying one third of the Central Himalaya. It has 8 peaks above $8,000 \mathrm{~m}$. in the altitude. The world's highest peak Mt. Everest also lies in the Nepal Himalaya.

Nepal, a small kingdom in the heart of the Asia, lies in the central sector of the Himalaya and has a rich flora with in the its boundaries which are about $150 \mathrm{Km}$. in breadth and $900 \mathrm{Km}$. in length. Some 6,500 species of seed plants are known to occur. The country extends from $80^{\circ} 15$ to $80^{\circ} 10 \mathrm{E}$ longitude and $26^{\circ} 20$ and $30^{\circ} 10 \mathrm{~N}$ latitude. It lies on the "cross-road " of various bio-climatic regions of the Asia and it has been a "meeting place" for a number of floristic provinces, such as the Sino-Japanese, the Irano-Turranian, the Central Asiatic and South-East Asian and Indo- Malayan regions (Appendix 3, Fig 1). The topographical feature of Nepal with altitudinal variations from $60 \mathrm{~m}$. at southern Teria to over $8000 \mathrm{~m}$. towards the third pole of the Himalayas has a wide range of habitat which has more than 10 different bio-climatic zones (Dobremez; 1972). So its various sort of environmental factors have provided diverse habitat for beautiful and rich flora which is rather of a mix of two different floras of humid Eastern Himalaya and drier Western Himalayas. It is a paradise for naturalists. Thus Nepal is very rich in terms of biological species as compared to relatively small of 147,181
$\mathrm{sq} . \mathrm{Km}$.

\section{VEGETATION}

The vegetation of Nepal has been divided by many workers into various phyto-geographical divisions. For the botanical purposes three divisions of Nepal has been proposed by Stearn (1960) and Banarjii (1963) corresponding to three big rivers systems; Karnali, Gandaki and Koshi. Swan and Laviton (1962) identified seven floristic zones based on moist habitats. Stainton (1972) described the vegetation of Nepal on the ground of ecology and vegetation composition under seven divisions 


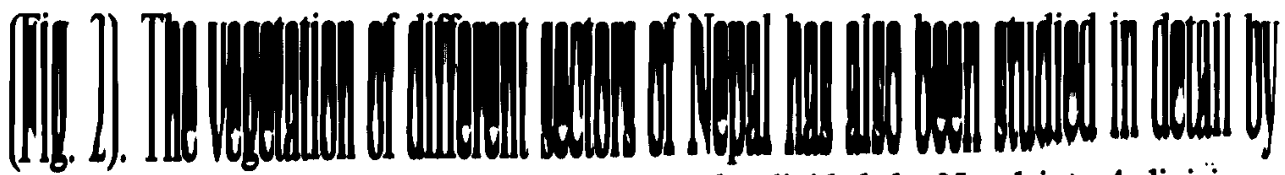

various workers, such as by Dobremez (1972) who divided the Nepal into 4 divisions, Bio-climatically he has identified twenty regions from humid tropical climate to the alpine and arid zone( Fig 3). Dobremez and Shakya (1975) studied the vegetation of East Nepal, Joshi et. al. (1975) in the Central Nepal and Dobremez and Shrestha (1976) in Western Nepal. In the same manner Japanese botanists Hara $(1966,71,78,79, \&$ 82) Ohashi $(1975)$ Ohba $(1982,86)$ etc. studied the detail floristic composition of East Nepal. A small country Nepal has almost all types of world vegetation squeezed in the peculiar topography of the country representing on the basis of altitude and with different types of climate.

A General picture of Nepalese flora and vegetation is out-lined as following.

\section{TROPICAL REGION}

Teria, Bhabar, Dun valley and Outer foot hills lies below $1000 \mathrm{~m}$. altitude and come under the tropical zone. It is their lower most regions of the country which is running parallel to the southern border with India. This region is hot during the summer with maximum temperature $45^{\circ} \mathrm{C}$ and minimum $0^{\circ} \mathrm{C}$ during the winter and annual average rainfall is $700-1000 \mathrm{~mm}$. Natural vegetation consists of tropical semi-evergreen monsoon forest. It consists of many kinds of deciduous trees pre-dominant one being the "Sal" tree, Shorea robusta. The other species associated with Sal forest are Adina cordifolia (Karma), Dillenia pentagyna (Tatari), Terminalia bellirica (Barro), $T$. chebula, T. myriocarpa (Panisaj), T. alata (Asna), Anogeissus latifolius (Banki), Lagerstroemia parviflora (Hade), Syzygium cumini (Jamuna), Schleichera oleosa (Kumsum), Lannea coromandelica (Bara, dabdabi), Bombax ceiba (Simal), Ehretia laevis (Datingal), Mallotus philippensis (Sindhure), Duabanga grandiflora (Lampate), Toona ciliata (Toona), Xylosma longifolum, Bauhinia malabarica, Careya arborea, Holarrhena pubescens, (Indrajaw), etc. While Dalbergia sissoo (Sissom) and Acacia catechu (Khayer), pre-dominate the new alluvial and gravel terraces along rivers. Riverain forest includes Albizia julibrissin (Padke siris), Cassia fistula (Rajbrilshya), Schleichera oleosa, Trewia nudifloro (Gamari), etc. Some common shrubs and herbs of this zone are Justicia adhatoda (Asuro), Butea minor (Bhuletro), Caesalpinia decapetata (Arilekanda), Clerodendrum viscosum (Rajbali), Colebrookea oppositifolia (Dhusure), Mimosa rubicaulis (Boksighans), Zizyphus mauritiana etc. Some South Asiatic flora like Cyathea spinulosa (Chhatare unue), Cycas pectinata (Thakal), Gnetum montanum, Podocarpous neriifolius (Gunsi), etc are found in the Eastern part of the region and these species go on decreasing towards Western Nepal up to Central Nepal (Pokhara). These are becoming threatened and endangered from Nepal.

Some of the medicinal plants of this region are Rauvolfia serpentina (Sarpaganda), Buxus orelana (Sindhur), Papaver somniferum (Aphium), Cyamopsis 
Some of the shrubs and herbs of this region are Arisaema speciosum (Sarpa ko makai), Camellia kissi (Chya pate), Cassia mimosoides Justicia procumbens (Phulphar), Sarcococca coriacea (Phitphiya), Viburnum erubescens (Bajrang), etc. Medicinal plants are Mahonia napaulensis (Jamane mandro), Dioscorea bulbifera (Gittha) D. deltoidea (Vyakur), D. belophylla (Tarul), Sapindus mukorossi (Rittha), Datura stramonium (Datura) Justicia adhatoda (Asuro), Achyranthus aspera (Apamarge), Lyonia ovalifolia (Angeri), Holarrhena pubescens (Indrajow), Gelina arborea (Kuamari) Martynia annua (Gridhankki), Equisetum debile (Kukure ghans), Cinnamomum tamala (Tejpat), C.zeylanicum (Dalchini), Elaeocarpus sphaericus (Rudrakshya), Jatropa curcas (Sajiban), Sida rhombifolia (Sano chillya) Breynia retusa (Sano nundhiki), Piper longum (pipla), Viscum articulatum (Hadchur), Dendrophthoe falcata (Ajeru), Euodia fraxinifolia (Kanukpa) etc.

In this region the Bamboos are the principle component of the grass land such as Dendrocalamus hamiltonii (Tama bans), Eulaliopsis binata (Babiyo), Pennisetum polystachion (Dina nath ghans), Saccharum bengalense (Munj), S.spontaneum (Kans) etc.

In Western Nepal, the sub-tropical zone is not so extensive nor is the so rich in the flora. Here the upper limit of the zone is at about $1400 \mathrm{~m}$. The top canopy of the forest is composed exclusively of Pinus roxburghii with poor representation of ground vegetation. However some shrubs and herbs are Inula cappa (Kanpate), Phyllanthus amarus, Wendlandia coriacea (Dhaiyaro), are scarcely found. In the deep galleys in the pine forest a few Quercus semecarpifolia (Kharsu) trees with certain quantities of Rhododendron, Lyonia ovalifolia (Anjir), usually occur. Other shrubs and herbs species associated are Buddleja paniculata , Gaultheria fragrantissima (Dhasingare), Jasminum officinale (Lahare jai), Reinwardtia indica (Pyauli) etc.

\section{TEMPERATE REGION}

Above the Sub-tropical zone lies the temperate zone, which extends upwards to tree-line. The altitude of the tree-line is much influenced by various aspects such as rainfall and the hand of man. This zone includes principally the Mahabharat range which lies almost parellel and north to south hills from east to west. This region falls at an altitude of $2000-3000 \mathrm{~m}$. and represented by a cool and humid climate. Summer is moderately hot and winter very cold with average annual rainfall $1500-2700 \mathrm{~mm}$. and snow fall is comparatively more. The lower part of temperate zone is largely under cultivation, but higher up there are extensive forest of evergreen oak, Rhododendrons, and Laurels are common in the Eastern and Central Nepal, where as Western Nepal is dominated by evergreen coniferous and deciduous mixed forest. It is this zone a heavy interaction between man, mountains and vegetation is under a heavy going. Human habitation and cultivation of crops usually stops at $2000 \mathrm{~m}$. On the south of the main 
tetragondoba (Gaur gum), Acorus calamus (Bojho), Catharanthus roseus (Barhamase), Solanum diffusum (Kantakari), Semecarpus anacardium (Bhalaya), Hemidesmus indicus (Ananta mul), Clitoria ternatea (Aparajita), Calotropis gigantea (Ank), Vetiveria zizanioides (Khas), Tinospora cordifolia (Gurjo), Operculina turpethum (Nishotha), Azadirachta indica (Neem) Butea monosperma, Mussaenda frondosa (Asari), Mucuna nigricans (Kauso) Eulophia campestris (Halti paile) Antidesma bunius (Himal cheri) Commelina benghalensis (Ban kane), Curcuma angustifolia (Barkhe sarro), Leea macrophylla (Bulevettra), Argyreia nervosa (Sumundra phool), Acacia rugata (Sikakai), Floscopa hamiltonii (Sim kane ghans), Utricularia bifida (Sim ghans), Cassia fistula (Rajbrikshya) etc.

Although most of the land has come under cultivation in this region cash crops cultivated are Saccharum officinarum (Ukhu), Nicotiana tabacum (Surti), Corchorus capsularis (Jute) Thea sinesis (Chiya).

\section{SUBTROPICAL REGION}

The midlands of Nepal lying between the crest of the Himalayas and the Mahabharat range consist of hills and mountains with valleys, gorges and terraces. Before malaria was eradicated from the tropical region, the midlands were the main homeland for nepalese people. Most of the midlands comes under sub-tropical and temperate zone. The altitudinal range for sub-tropical zone lies between $1000 \mathrm{~m}$. and $2100 \mathrm{~m}$.and having hot summer of maximum temperature $27^{\circ} \mathrm{C}$ and moderately cold winter. The average annual rainfall is $1000-2000 \mathrm{~mm}$. In this region the leafless forest is most prominent in the spring. The dominant trees is Schima-Castanopsis (Chilaune-Katush) forest are Schima wallichii (Chilaune), Castanopsis indica (Katush), in the lower belt while C.tribuloides (Musure Katus) replace C.indica in the upper belts in the Central and Eastern Nepal. While in the Western Nepal this zone is characterized by the occurrence of Pinus roxburghii (Chir pine) forest. Other trees species associated with this zone are Alnus nepalensis (Utis), Anthocephalus chinensis (Kadam), Toona ciliata (Tooni), Engelhardia spicata (Mauwa), Erythrina arborescens (Theki Kath), Juglans regia (Okhar), Ficus semicordfolia, Ilex excelsa (Puwale), Lithocarpus elegans (Arkaule), Macaranga denticulata, Michelia champaca (Champ), Rhododendroin arborium (Lali guras), Saurauia napaulensis (Gogan), etc. To-day the sub-tropical region of Nepal is perhaps a unique site for demonstrating example of deforestation, land slides, a and soil erosion. A large number of valuable plants are already threatened to extinction and many more are facing a precarious existence some of the finest plants like Michelia champaca, M. velutina (Sunachamp), Talauma hodgsonii, Prunus carmesina, are and number of epiphytic and terrestrial orchids and ferns have already become very rare. 
Himalayan range. Thus virgin forest with large number of indigenous plants are to be seen only beyond $2400 \mathrm{~m}$.. It is the zone of distinct evergreen coniferous forest and deciduous mixed forest. Laurels and evergreen oak forest are found in the lower parts of Betula alnoides is associated with Acer oblongum (Phiphire), Alnus nepaulensis (Utis), Daphniphyllum (Paiya), Castanopsis tribuloides, C. hystrix, Cinnamomum tamala, (Pahenli), Persea duthiei (Rakchan), Ilex dipyrena, Lindera bifaia, Litsea ablonga

Mixed broad-leaved deciduous forest in the upper temperate zone has Acer campbellii (Yaarla), Corylus ferox, Magnolia campbellii (Ranichamp), Osmanthus suovis (Siling) etc and are they the typical species of this zone growing mostly on the north and west facing slopes of the Himalaya range. The other trees of this zone are Acer thomsonii, Betula alnoides, Euonymus tingens (Kasuri), Lidera pulcherrima Tsuga dumosa ashia, Populus ciliata (Bange kath) and Prunus cornuta (Arupate), broad-leaved forest Qurecus lamellosa (Phalat) also often present in this forest. The (Koringa), R.fulgens, Eastern side in Nepal. Simile (Patukorlinga), R.hodgsonii are distributed in the (Deodar), Pinus wallichiana (Gily Western Himalaya elements like Cedrus deodara in the above region by Cupreobre salla), are an importance constituent and succeeds Juglans regia, Aesculus The other associated indica (Karu), are common in the western side of the country. jacquemontii, Morus trees are Abies pindrow, Acer cappadocicum, Corylus of the endangered species of Nepal.

The common shrubs and herbs associated with the Laurels evergreen oak and mi :ed broad-leaved deciduous forest are Berberis aristata (Chutro), Boehmeria macrophylla, Daphne papyracea (Bhulu), Holboellia latifolia (Guphala) Lyonia ovalifolia (Anjir), Mohania napaulensis, Piptanthus nepalensis, Schisandra grandiflora (Singato) and Arundinaria aristata (Malingo). They come up whenever the forest is opened out. In the Western Nepal the ground vegetation has a very poor growth of shrubs and herbs due to the presence of evergreen coniferous forest. Some of the shrubs and herbs like Berberis chitria, Clematis montana, Deutzia compacta, Leycesteria formosa, Rosa sericea, Sorbaria tomentosa, etc are found in Western Nepal.

The temperate region of Nepal Himalayas is the home land of orchids. There are more than 300 species, which is both epiphytic and terrestrial habits are Aerides multiflora, Arundina graminifolia, Bulbophyllum dyerianum, $B$. hookeri, $B$. mannii, C. masuca, C plantagine viridiflorum, Calanthe alpina, C. brevicornu, $C$. C. ochrecea, Cymbidium iginea, C. tricarinata, Coelogyne corymbosa, C. cristata, Cryptochillus luteus, C. longifolium, Cypripedium cordigerum, Dendrobium amoenum, 
D.densiflorum, D. fimbriatum, D. moschatum, D. porphyidochlllin, Eplpaclls helleborine, Eria coronaria, E. excavata, E. amica, E. flava, E. paniculata, E. biflora, Kingidium taenialis, Pleione hookeriana, $P$. proecox, Rhiyachostylis retusa, Satyrium nepalense, Vanda cristata, V.terres etc.

Many medicinal plants are found in this region such as Valeriana jatamansii (Sugandhawal), Nardostachys grandiflora (jatamansi), Bergenia ligulata (Pakhanbed), Dictylorhiza hatagirea (Panch aungule), Picrorhiza scrophulariiflora (Kutki), Asparagus racemosus (Satabari), Swetia angustifolia (Chiraito), Aconitum spicatum (Bikh), Dryopteris filix (Unue), cotoneaster affinis (Kause phool), Podophyllum hexandrum (Laghu patre), Rhododendron campanulatum (Nilo chimal), Lobelia pyramidalis (Eklebir), Lycopodium clavatum (Nagbali), Persicaria chinensis (Kukur thotne), Gnaphalium luteo-album (Jyapughans), Smailex macrophylla (Kukurdaino), Potentilla fulgens (Bajradanti), Valeriana hardwickii (Nakali jatamansi), Blainvillea acemella (Lato ghans), Symplocos paniculata (Lodh), Paris polyphylla (Satuwa), Zanthoxylum oxyphyllum (Siltimur), Picris hieracioides (Ban dudhe), Rubia cordifolia (Manjitho) etc.

\section{SUBALPINE REGION}

The slopes of the Himalayan region above $3000 \mathrm{~m}$. to tree-line of about 4000 $m$. comes under the sub-alpine zone. This zone includes Inner and Outer Himalayas and Trans-Himalayan land in the North part of the country. The climate is extensively cold, dry, and windy. In this region is the most limiting factor for the growth of plants. This zone is perhaps the hest ground for plant hunters and nature lovers. This zone is characterized by coniferous forest of Abies spectabilis at lower level and tree-line vegetation however consists of Betula utilis (Bhojpatra) and Rhododendron cowanianum, R.grande, R.falconari etc. The number of Rhododendron species is maximum up to 32 in the Eastern Nepal and their number goes on falling towards Central and Western Nepal. In the Western Nepal, midland Acer acuminatum, Prunus cornuta, P.rufa, Picea smithiana, Sobrus cuspidata, and Taxus baccata var wallichii (Dengre. sallo) are associated. In this zone a large number of genera belonging to European flora are found. Some of the well known ones are Aconitum, Anaphalis, Androsace, Corydalis, Gentiana, Meconopsis, Polygonum, Potentilla, Primula, Sassurea, Saxifraga and so on. Among the shrubs and herbs most important ones are Clematis barbellata, Cotoneaster acuminatus, Daphne bholua (Kagat pate), Euonymus porphyreus, Lonicera webbiana, Primula denticulata, Rhododendron barbatum (Guras), R.companulatum, Ribes himalense, Rosa sericea, Salix bhutanensis, S.daltoniana, S.sikkimensis etc.

In the Central and Western mid-land Betula forest lies at upper level of this zone and Rhododendron campanulatum is most associated with it. The other associated 
species are Acer pectinatum, Juniperus recurva, Lyonia villosa, Potentilla fructicosa (Chiniya phool), Rhododendron lepidotum (Bhale sunpate), Sobrus foliosa etc. In the Western Nepal, this zone has a predominance of Quercus semecarpifolia on dry south facing slopes which is contrast to its paucity in Eastern Nepal.

Some of the medicinal plants of this zone are Aconitum heterophyllum (Atis), A.bafourii (Gobari), Ephedra gerardiana (Somlata), Selium tenuifolium (Bhutkesh) Potentilla fructicosa Delphinium denudatum (Nilo Bisk), Anemone rivularis (Ratanjot), Rheum emodi etc.

Some of the orchid flora is also distributed in sub-alpine region such as Coeloglossum viride, Corallorhiza trifida, Cyperipedium elgans, C.himalaicum, Epipogium aphyllum, and Habenaria species.

\section{ALPINE REGION}

Between the tree-line $(4000 \mathrm{~m}$.) and snow-line $(5000 \mathrm{~m}$.) the mountainous country of Nepal comes under alpine zone. The alpine zone is represented by moist alpine scrub and dry alpine scrub. In this area winter is severe and summer relatively short and cold. Precipitation is minimum in the form of snow and rain is scanty. There is lacking of timber and vegetation covers consists mainly of grasses, herbs and dwarf shrubs. Most of the plants are hairy and colored. This zone is particularly rich in the number of species, Shrestha (1982) has listed 16 woody species and 143 herbaceous species of plants from this zone in the Karnali region. Where as Ohba (1988) has listed 1227 species of plants of which 6 species are gymnosperm, 192 monocotyledons and 1029 dicotyledons from the whole alpine Himalaya of Nepal . Some species reach to areas near the snow line and are therefore sub-nival vegetation. The total number of Alpine flora of Nepal Himalaya with 29 genera is nearly half of the total number of alpine flora, which is common and diversified in both arctic and temperate region of Northern Hemisphere. (Appendix I) .

The highest altitudinal recording reporting of flowering plant in the world is to be found in Nepal. Shipton's collection of Saussurea gnaphaloides at about $6400 \mathrm{~m}$. altitude during his 1935 expedition to Mt. Everest is perhaps the most remarkable record of flowering plants in the world. In the alpine region in the moist alpine scrub; shrubberies rhododendrons are Rhododendron compylocarpum, R.fulgens, R.wightii, while are characteristic features in the Eastern midland. Besides these R.anthopogon (Guras), R.lepidotum, R.pumilum, R.setosum, Juniperus recurva, Lonicera obovata, Salix sikkemensis etc. form dense carpet in some place. In Central and Western midlands of this zone is Betula utilis, as the main component is associated with the least frequent Juniperus indica, Lonacera obovata, Potentilla fructose shrubby rhododendrons etc. Some of beautiful plants of this belts now cultivated in the Western 
countmes are of Anemone obtusiloba, Campanula aristata, Corydalis meifolia, C.ramosa, Delphinium dictycarpum, D.vertitum, Epilobiumm conspermum, Fritillaria cirrhosa, Gentiana depressa, G. prolata, G. venusta, Meconopsis horridula, M.simplicifolia, Primula calderina, P.capitata, Rhododendron nivale: the smallest bushy rhododendron, Saussurea gossypiphora (Kapase phool), S.obvallata, Saxifraga aristulata, S.brunonis, S.grandufera, S.mallae etc.

Dry alpine scrub vegetation are found in the inner valleys, such as Juniperus recurva which are found in the lower belt and J.indica, J.squamata in the upper belt in the Eastern and Central region of this zone. The increasing dry condition at upper level are marked by the occurrence of Ephedra geradiana, Hippophae tibetiana, Myricaria germanica, on riverside terraces. In this zone the shrub do not grow over $1.25 \mathrm{~m}$. in height, so that in this region Caragana gerardiana, Ephedra gerardiana, E.intermidia and Sophera mooeroftiana etc grow in abundance.

The alpine meadows are subjected to grazing in summer and rainy season. They are covered by herbs like Cortia depressa, Kobresia hookerii, K.trinervis, and other species of Agrostis munroana, Carex atrofusca, C.cordioleps, C.segitera, Caltha palustris, Geranium polyanthes, Potentilla peduncularis, Primula obliqua etc.

\section{CONCLUSION}

The vegetation described above is typical representation in the different region of Nepal. The variety in the vegetation of Nepal thus range from the tropical to alpine species and from east to west region owing to variation of aspect, altitude, geography etc. The Himalayas is the "meeting place" of different floristic elements entering from different directions. Thus, Nepalese flora is not only represented by a mix of the differing Eastern Himalayan humid flora with that of the drier Western one on the Southern slopes of Himalayas, but also a mix of high and dry plateau flora of Tibet with that of the humid monsoon region of Indian Sub-continental plains floras. Besides it has a rich heritage of endemic and monogeneric plants (Appendix II and III) as well.

Therefore, the glory of Nepal could well be established comforted on the basis of its typical natural vegetation, but on the face of present situation, it is evident that this will not last long, if immediate effective measures of preservation are not taken. The depletion of vegetation in the tropical and sub-tropical regions have already threatened a large number of plants from extinction. It is a time to take care of these vegetation by conservation of the forest So that our natural heritage of Nepalese flora has a global importance and it is our national responsibility to preserve them not only to highlight natural heritage but also to safeguard their genetic values which has not yet been explored for the development. 
APPENDIX: I

\begin{tabular}{|l|c|c|c|c|c|}
\hline \multicolumn{1}{|c|}{ Genus } & $\begin{array}{c}\text { No. of sp. } \\
\text { Nepal }\end{array}$ & $\begin{array}{c}\text { No. of sp. } \\
\text { in world }\end{array}$ & $\begin{array}{c}\text { Type } \\
\text { species }\end{array}$ & $\begin{array}{c}\text { Endemic } \\
\text { sp. }\end{array}$ & $\begin{array}{c}\text { List Obba } \\
\text { Himal }\end{array}$ \\
\hline Saxifraga & 76 & 370 & 22 & 14 & 74 \\
Pedicularis & 63 & 500 & 29 & 11 & 55 \\
Primula & 62 & 500 & 11 & 5 & 48 \\
Carex & 61 & 2000 & 5 & - & 23 \\
Gentiana & 44 & 400 & 7 & 3 & 31 \\
Impatients & 40 & 700 & 13 & 12 & - \\
Saussurea & 36 & 400 & 10 & 5 & 29 \\
Aconitum & 36 & 300 & 16 & 12 & 18 \\
Ficus & 33 & 800 & 2 & - & - \\
Rubus & 32 & 250 & 12 & 2 & - \\
Cotoneaster & 32 & 50 & 11 & 6 & - \\
Berberis & 30 & 450 & 5 & - & 12 \\
Rhododendron & 30 & 600 & 7 & 2 & - \\
Salix & 30 & 500 & 5 & 3 & 17 \\
Juncus & 30 & 300 & 3 & - & 17 \\
Poa & 29 & 300 & 7 & 5 & 18 \\
Astragalus & 29 & 2000 & 2 & 1 & 12 \\
Corydalis & 28 & 320 & 9 & 7 & 27 \\
Swertia & 28 & 100 & 9 & 2 & 15 \\
Persicaria & 27 & 150 & 8 & - & - \\
Cyprus & 27 & 550 & 2 & - & - \\
Potentilla & 25 & 500 & 7 & - & 17 \\
Silene & 24 & 500 & 9 & 6 & 15 \\
Seneclo & 24 & $2-3000$ & 14 & 3 & - \\
Kobresia & 24 & 50 & 5 & 5 & 16 \\
Clematis & 23 & 250 & 9 & 3 & - \\
Euphorbia & 22 & 2000 & 3 & - & - \\
Lonicera & 22 & 200 & 6 & - & 11 \\
Deplphinium & 20 & 250 & 5 & 2 & 12 \\
Ranunculus & 20 & 400 & 2 & 2 & 11 \\
Thalictrum & 20 & 150 & 5 & 2 & - \\
Rhodiola & 20 & 50 & 6 & 4 & 19 \\
Arenaria & 19 & 250 & 4 & 2 & 17 \\
Begonia & 18 & 900 & 10 & 4 & - \\
Crotalaria & 17 & 550 & 3 & 1 & - \\
Epilobium & 17 & 215 & 6 & - & - \\
\hline
\end{tabular}




\begin{tabular}{|l|c|c|c|c|c|}
\hline \multicolumn{1}{|c|}{ Genus } & No. of sp. & No. of sp. & Type & Indemic & Ulst Ohba \\
in world & species & sp. & Himal \\
\hline Anaphalis & 17 & 35 & 1 & - & - \\
Aster & 17 & 500 & 2 & - & 12 \\
Androsace & 17 & 100 & 3 & - & 10 \\
Arisaema & 17 & 150 & 6 & 3 & 1 \\
Habenaria & 16 & 600 & 2 & - & - \\
Anaphalis & 17 & 35 & 1 & - & - \\
Aster & 17 & 500 & 2 & - & 12 \\
Androsace & 17 & 100 & 3 & - & 10 \\
Arisaema & 17 & 150 & 8 & 3 & 1 \\
Habenaria & 16 & 600 & 2 & - & - \\
SteLlaria & 16 & 120 & 4 & 3 & - \\
Sedium & 16 & 600 & 2 & 1 & - \\
Solanum & 16 & 1700 & 1 & - & - \\
Artemisia & 15 & 400 & 1 & 1 & - \\
Veronica & 15 & 300 & 3 & 1 & - \\
Draba & 15 & 300 & 2 & 2 & 12 \\
Hypericum & 15 & 300 & 5 & - & - \\
Prunus & 15 & 400 & 5 & 2 & - \\
Smilax & 15 & 430 & 2 & - & - \\
Meconopsis & 14 & 350 & 4 & 4 & 12 \\
Geranhium & 14 & 42 & 3 & - & - \\
Viola & 14 & 400 & - & - & - \\
Taraxacum & 14 & 500 & 6 & 4 & - \\
Jasminum & 14 & 60 & 2 & 1 & - \\
Pilea & 14 & 300 & 4 & 2 & - \\
Elatostema & 13 & 400 & 4 & - & - \\
Lindernia & 13 & 200 & 2 & - & - \\
Cremanthodium & 13 & 80 & 2 & - & 12 \\
Acer & 13 & 55 & 5 & - & - \\
Anemone & 13 & 200 & 7 & 1 & 11 \\
Oxytropsis & 13 & 150 & 7 & 7 & 12 \\
Eriocaulon & 13 & 300 & 6 & 5 & - \\
Dioscorea & 13 & 400 & 1 & - & - \\
Hedychium & 12 & 600 & 7 & - & - \\
Blumea & 12 & 50 & 1 & - & - \\
Codonopsis & 12 & 50 & 4 & 1 & - \\
Didymocarpus & 12 & $30-40$ & 6 & - & - \\
Litsea & 12 & 120 & 4 & - & - \\
\hline
\end{tabular}


PHYTO-GEOGRAPHY OF

67

\begin{tabular}{|c|c|c|c|c|c|}
\hline Genus & $\begin{array}{l}\text { No. of sp. } \\
\text { Nepal }\end{array}$ & $\begin{array}{l}\text { No. of sp. } \\
\text { in world }\end{array}$ & $\begin{array}{c}\text { Type } \\
\text { species }\end{array}$ & $\begin{array}{c}\text { Endemic } \\
\text { sp. } \\
\end{array}$ & $\begin{array}{c}\text { List Ohba } \\
\text { Himal }\end{array}$ \\
\hline Rabdosia & 11 & 400 & 4 & 2 & - \\
\hline Nepata & 11 & 250 & 2 & - & - \\
\hline Gentianella & 11 & 125 & 1 & - & - \\
\hline Elymus & 11 & 70 & 2 & 2 & - \\
\hline Oberonia & 14 & 330 & 2 & - & - \\
\hline Cardamine & 10 & 160 & 1 & - & - \\
\hline Euonymus & 10 & 176 & 7 & - & - \\
\hline Caragana & 10 & 80 & 1 & 1 & - \\
\hline Rosa & 10 & 250 & 3 & - & - \\
\hline Ga;oi, & 10 & 400 & 3 & - & - \\
\hline Elsholtzia & 10 & 35 & 2 & - & - \\
\hline Phyllanthus & 10 & 600 & 2 & - & - \\
\hline Lomatogonium & 9 & 18 & 2 & - & - \\
\hline Cyananthus & 9 & 30 & 2 & 1 & - \\
\hline Symplocos & 9 & 350 & 3 & - & - \\
\hline Polygola & 9 & $5-6000$ & 2 & - & - \\
\hline Ilex & 9 & 400 & 3 & - & - \\
\hline Indigofera & 9 & 700 & 1 & - & - \\
\hline Chrysosplenium & 9 & 55 & 1 & - & - \\
\hline Polygonatum & 9 & 50 & 3 & - & - \\
\hline Herminium & 9 & 30 & 2 & - & - \\
\hline Cymbidium & 9 & 40 & 2 & - & - \\
\hline Goodyyear & 8 & 40 & 1 & - & - \\
\hline Peristylus & 8 & 60 & 3 & - & - \\
\hline Eleocharis & 8 & 200 & 1 & - & - \\
\hline Cymbopogon & 8 & 60 & 2 & - & - \\
\hline Stipa & 8 & 300 & 1 & 1 & - \\
\hline Viburnum & 8 & 200 & 5 & - & - \\
\hline Pleurospermum & 8 & 80 & 6 & - & - \\
\hline Ribes & 8 & 150 & 1 & - & - \\
\hline Dalbergia & 8 & 300 & $\begin{array}{l}1 \\
1\end{array}$ & - & - \\
\hline $\begin{array}{l}\text { Zizyphus } \\
\text { Inula }\end{array}$ & $\begin{array}{l}8 \\
8\end{array}$ & $\begin{array}{l}100 \\
200\end{array}$ & $\begin{array}{l}1 \\
2\end{array}$ & 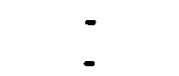 & - \\
\hline $\begin{array}{l}\text { Inula } \\
\text { Leontopodium }\end{array}$ & $\begin{array}{l}8 \\
8\end{array}$ & $\begin{array}{c}200 \\
30\end{array}$ & 1 & 1 & - \\
\hline $\begin{array}{l}\text { Leontopodium } \\
\text { Lobelia } 8\end{array}$ & $\begin{array}{l}8 \\
8\end{array}$ & $\begin{array}{c}30 \\
2\end{array}$ & - & - & - \\
\hline $\begin{array}{l}\text { Lobelia } 8 \\
\text { Scrophularia }\end{array}$ & $\begin{array}{l}8 \\
8\end{array}$ & $\begin{array}{c}2 \\
300\end{array}$ & 3 & 2 & - \\
\hline $\begin{array}{l}\text { Scrophularia } \\
\text { Bistorta }\end{array}$ & $\begin{array}{l}8 \\
8\end{array}$ & $\begin{array}{c}300 \\
50\end{array}$ & 2 & - & - \\
\hline
\end{tabular}




\begin{tabular}{|c|c|c|c|c|c|}
\hline Ger & Nepal & Np of 19 & $\prod_{\text {species }}^{\text {Type }}$ & $\begin{array}{c}\text { Endemic } \\
\text { sp. }\end{array}$ & $\begin{array}{c}\text { List Ohba } \\
\text { Himal } \\
\end{array}$ \\
\hline Persea & 8 & 150 & 2 & - & - \\
\hline Boehmeria & 8 & 100 & 1 & - & - \\
\hline Glochidion & 8 & 300 & 1 & 1 & - \\
\hline Lindera & 8 & 100 & 3 & - & - \\
\hline Cinnamomum & 7 & 250 & 2 & - & - \\
\hline Scutellaria & 7 & 300 & 2 & - & - \\
\hline Limnophilia & 7 & 30 & 1 & - & - \\
\hline Hoya & 7 & 200 & 5 & - & - \\
\hline Gaultheria & 7 & 200 & 1 & - & - \\
\hline Cirsium & 7 & 150 & 4 & 3 & - \\
\hline Zanthoxylum & 7 & 20-30 & 1 & 1 & - \\
\hline Rhamnus & 7 & 110 & 1 & - & - \\
\hline Rhus & 7 & 250 & 1 & 1 & - \\
\hline Sibbaldia & 7 & 20 & 2 & 1 & - \\
\hline Osbcekia & 7 & 100 & 4 & - & - \\
\hline Heracleum & 7 & 70 & 3 & - & - \\
\hline PimpineLla & 7 & 150 & 2 & - & - \\
\hline Wendlandia & 7 & 70 & 4 & 1 & - \\
\hline Bromus & 7 & 50 & 2 & 2 & - \\
\hline Eulophia & 7 & 200 & 2 & - & - \\
\hline Malaxis & 6 & 300 & 4 & 1 & - \\
\hline Iris & 6 & 300 & 2 & 1 & - \\
\hline Allium & 6 & 450 & 2 & 1 & - \\
\hline Lillium & 6 & 80 & 1 & - & - \\
\hline Ophiorrhiza & 6 & 150 & 3. & 1 & - \\
\hline Mussaenda & 6 & 200 & 3 & - & - \\
\hline Brassaiopsis & 6 & 35 & 3 & - & - \\
\hline Rotala & 6 & 50 & 1 & - & - \\
\hline Parnassia & 6 & 50 & 2 & - & : \\
\hline Rhynchosia & 6 & 300 & 2 & 1 & - \\
\hline Milletia & 6 & 180 & 1. & 1 & - \\
\hline Buddleja & 6 & 100 & 1 & - & - \\
\hline Euphorosia & 6 & 200 & 2 & - & - \\
\hline Rheum & 6 & 50 & 1 & 1 & - \\
\hline Rumex & 6 & 200 & 2 & - & - \\
\hline Elaeagnus & 5 & 45 & 5 & 1 & - \\
\hline Aristolochia & 5 & 350 & 1 & - & - \\
\hline Koenigia & 5 & 7 & 1 & - & - \\
\hline Aconogonum & 5 & 15 & 2 & - & - \\
\hline
\end{tabular}




\section{APPENDIX: II}

\begin{tabular}{|c|c|c|c|}
\hline \multirow[t]{2}{*}{ Family } & \multicolumn{2}{|c|}{ No. of species in } & \multirow[t]{2}{*}{ Nepalese species } \\
\hline & World & Nepal & \\
\hline $\begin{array}{l}\text { Azollaceae } \\
\text { Equisetaceae } \\
\text { Parkeriaceae } \\
\text { Plagiogyriaceae } \\
\\
\text { Saviniaceae } \\
\text { Selaginellaceae }\end{array}$ & $\begin{array}{c}6 \\
23 \\
2 \\
36\end{array}$ & $\begin{array}{c}1 \\
17\end{array}$ & $\begin{array}{l}\text { Azolla imbricata(Roxb.)Nakai } \\
\text { Equisetum debile Roxb.ex vauch. } \\
\text { E. diffusum D.Don } \\
\text { Ceratopteris siliquosa (L) Copel. } \\
\text { Plagiogyria communis Ching } \\
\text { P. euphiebia (Kunze) Mett. } \\
\text { P. Picnophylla (Kunze) Mett. } \\
\text { Salvinia natans (L.) All. } \\
\text { Selaginella biformis A.Br. } \\
\text { S. bisulcata Spring } \\
\text { S. bryopteris (L.) Bak. } \\
\text { S. chrysocaulos (Hook.et Grev)spr. } \\
\text { S. chryorhizos Spring } \\
\text { S. ciliaris (Ratz.) Spring. } \\
\text { S. fulcrata (Ham.) Spring. } \\
\text { S. involvens (Sw.) Spring. } \\
\text { S. kurzii Baker } \\
\text { S. monospora Spring. } \\
\text { S. pallida (Hook et Grev.) Spring. } \\
\text { S. pennata (D.Don) Spring. } \\
\text { S. pubescens (Wall.) Spring. } \\
\text { S. repanda (Desv.) Spring. } \\
\text { S. subdiaphana (Wall) Spring. } \\
\text { S. tenuifolia Spring. } \\
\text { S. vaginata Spring. }\end{array}$ \\
\hline $\begin{array}{l}\text { Gymnosperms } \\
\text { Cycadaceae } \\
\text { Gnetaceae } \\
\text { Ginkgoaceae } \\
\text { Ephedraceae }\end{array}$ & $\begin{array}{c}20 \\
30 \\
1 \\
40\end{array}$ & $\begin{array}{l}1 \\
1 \\
4\end{array}$ & $\begin{array}{l}\text { Cycas pectinata Griff. } \\
\text { Gnetum montanum Markgr. } \\
\text { Ginkgo biloba L. } \\
\text { Ephedra gerardiana Wall ex Stapf } \\
\text { E. intermedia Schrenk \& Meyer } \\
\text { E. pachyclada Boiss. } \\
\text { E. saxatilis Wall ex Stapf. } \\
\end{array}$ \\
\hline
\end{tabular}




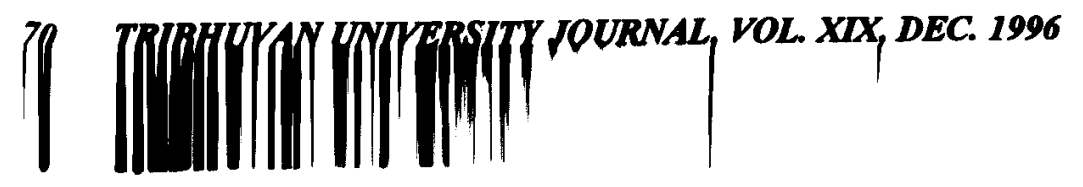

\begin{tabular}{|c|c|c|c|}
\hline \multirow[t]{2}{*}{ Family } & \multicolumn{2}{|c|}{ No. of species in } & \multirow[t]{2}{*}{ Nepalese species } \\
\hline & World & Nepal & \\
\hline $\begin{array}{l}\text { Angiosperms } \\
\text { Monocotyledons } \\
\text { Cannaceae } \\
\text { Najadaceae } \\
\text { Typhaceae }\end{array}$ & $\begin{array}{l}50 \\
10\end{array}$ & $\begin{array}{l}2 \\
2\end{array}$ & $\begin{array}{l}\text { Canna edulis Ker-Gawler } \\
\text { C. indica } \mathrm{L} \text {. } \\
\text { C. chinensis Willd. } \\
\text { C. speciosa Sims. } \\
\text { Naja graminea Delile } \\
\text { N. minor All. } \\
\text { Typha angustifolia } \mathrm{L} \text {. } \\
\text { T. elephantina Roxb. } \\
\end{array}$ \\
\hline $\begin{array}{l}\text { Angiosperms } \\
\text { Dicotyledons } \\
\text { Callitrichaceae } \\
\text { Circaeasteraceae } \\
\text { Coriariaceae } \\
\\
\text { Daphniphyllaceae } \\
\text { Datiscaceae } \\
\text { Hippuridaceae } \\
\text { Leeaceae }\end{array}$ & $\begin{array}{c}25 \\
1 \\
1 \\
15 \\
\\
10 \\
\\
2 \\
3 \\
70\end{array}$ & $\begin{array}{l}1 \\
1 \\
1 \\
1 \\
1 \\
1 \\
\\
1 \\
1 \\
1 \\
\end{array}$ & $\begin{array}{l}\text { Callitriche palustris L. } \\
\text { C. stagnalis Scopoli } \\
\text { Circaeaster agrestis Maxim. } \\
\text { Coriaria nepalensis Wall } \\
\text { C. terminalis Hemsl. } \\
\text { Daphniphyllum himalense (Benth } \\
\text { Muell- Arg. } \\
\text { Datisca cannabina L. } \\
\text { Hippuris vulgaris L. } \\
\text { Leea aequataq L. } \\
\text { L. alata Edgew. } \\
\text { L. compactiflora Kunz } \\
\text { L. crispa van Royen ex L. } \\
\text { L. guineensis G.Don } \\
\text { L. macrophylla Roxb. ex Hornem. } \\
\text { Moringa oleifera Lam. } \\
\text { Paeonia emodi Wall ex Royle } \\
\text { Phryma leptostachya L. } \\
\text { Punica grantum L. } \\
\text { Sphenoclea zeylanica Gaertn. } \\
\text { Stachyurus himalaicus Hook.f. \& } \\
\text { Thoms. ex Benth } \\
\text { Tetracentron sinense Oliv. } \\
\text { Toricellia tiliifolia DC. } \\
\text { Trapa quadrispinosa Roxb. }\end{array}$ \\
\hline
\end{tabular}




\section{APPENDIX III}

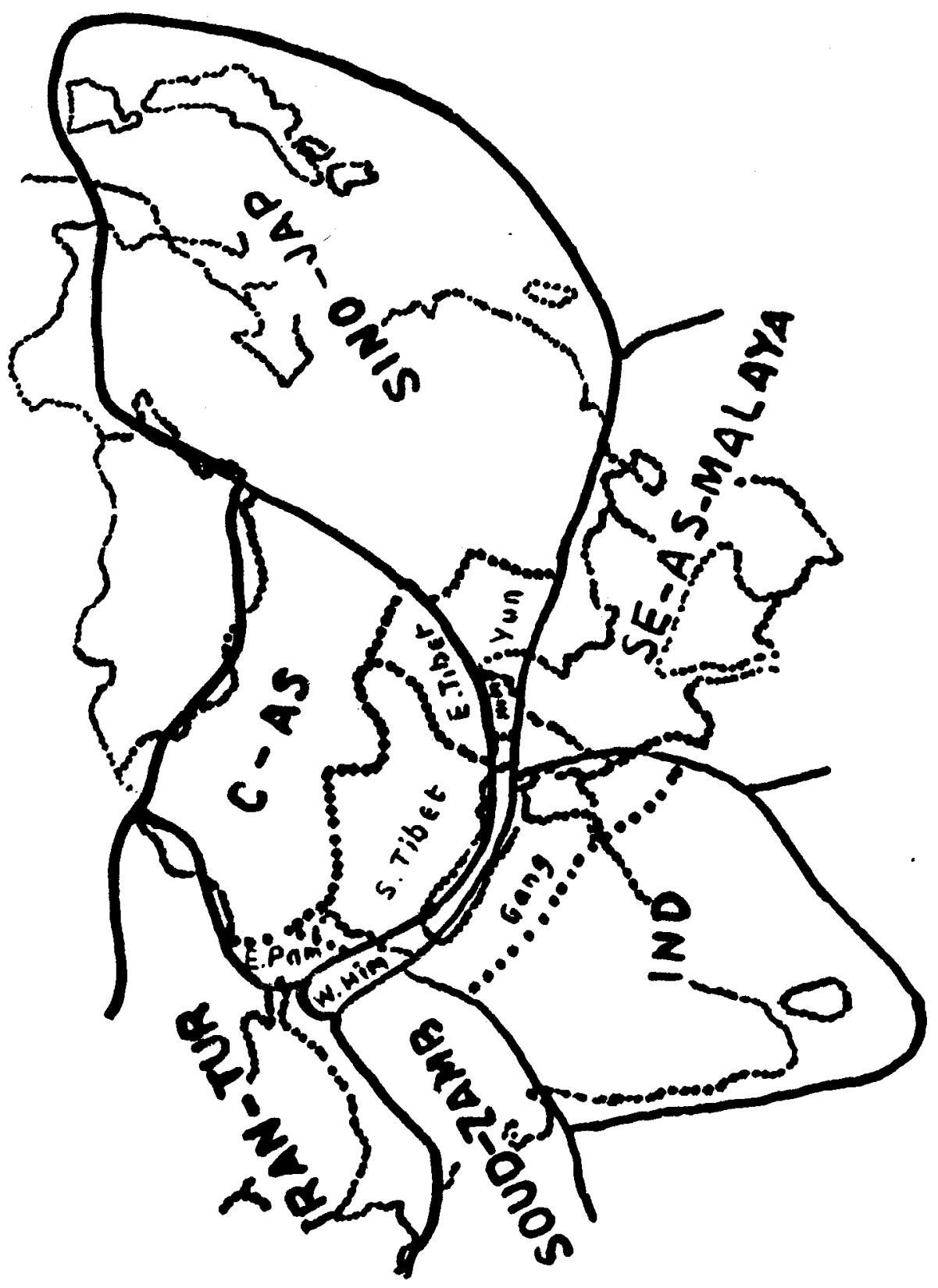

Fig. 1: Florestic composition of Asiatic region. 


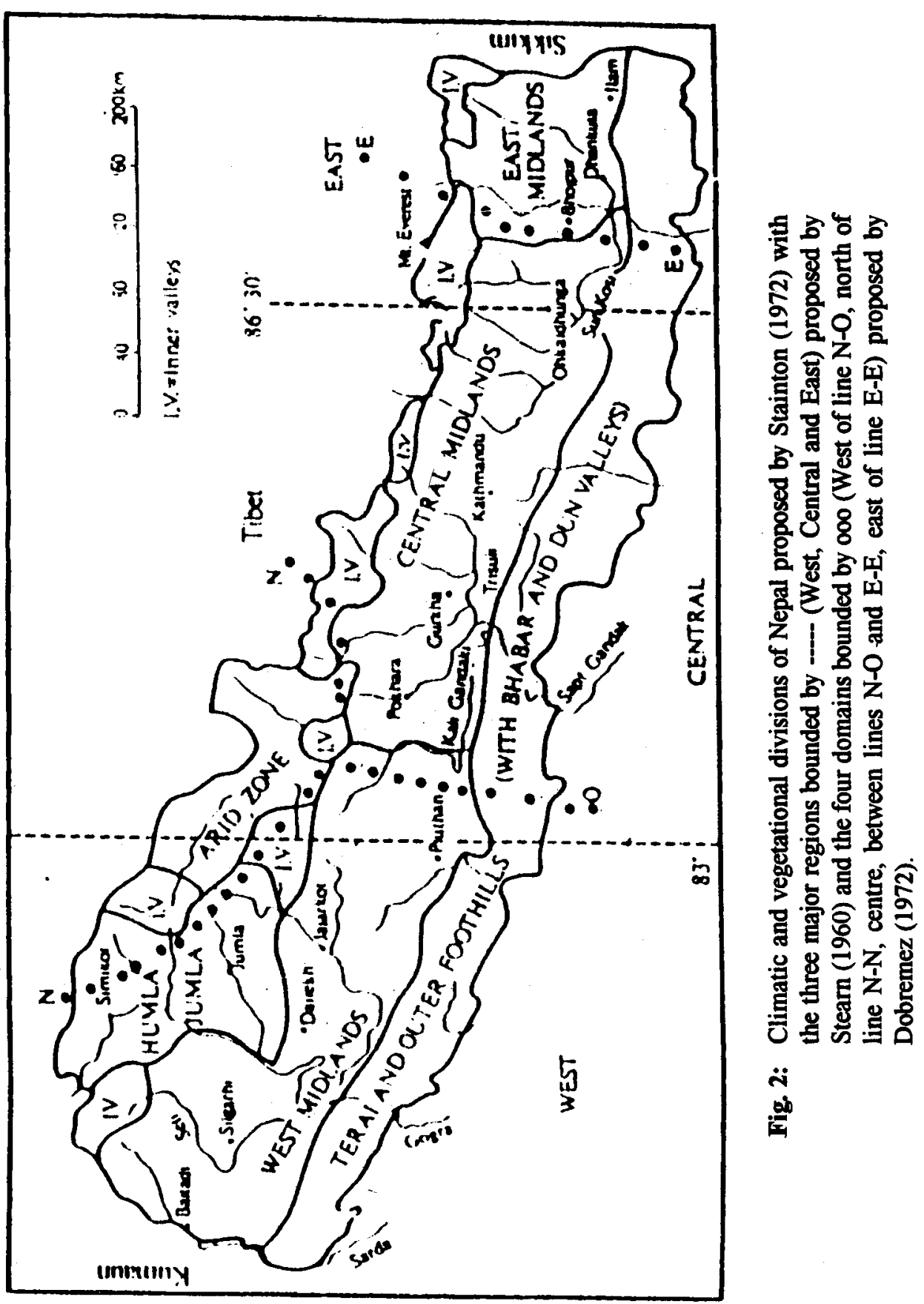


Fig. 3: Vegetation division of Nepal Himalaya (Dobremez, 1972).

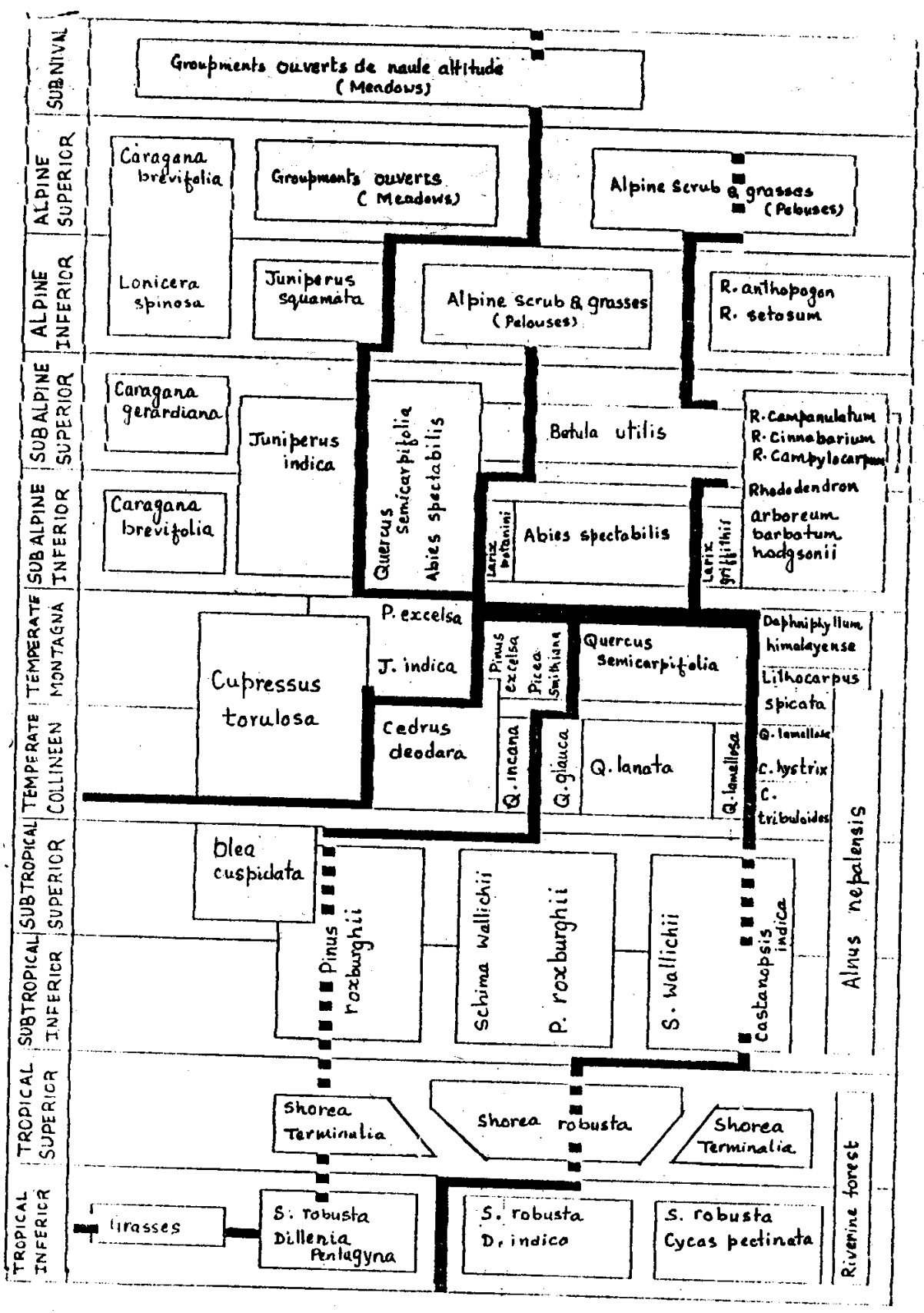




\section{WORKS GITPP}

Banerji, M. L., (1963), "Outline of Nepal Phytogeography Vegetacion" Acta Geobotanica. 11 Fasc. 2 (5-6) 288-296.

Banerji, M. L., (1973), "Nepal its forest and phytogeography." Glimpses in Plant Research. 1, 182-205.

Bhatta, D. D., (1977), "Vegetation." Natural History and Economic Botany of Nepal. 4361, Orient Longman Ltd. Calcutta. India.

Burkill, I. H., (1910), "Notes from a journey to Nepal." Rec. Bot Sur. Ind. 4. 59-140. India.

Department of Medicinal Plants HMG/Nepal (1975), "Catalogue of Nepalese Vascular Plants." Bull. Dept. Med. Nep. Vol.7 Nepal.

Dobremez, J. F., (1972), "Mise eu Point d'. une methode Cartographique d' etude des montanges tropicales Le Nepal," ecologic. Phytogeographie Univ. Grenoble. Bid. veg. Those.

Dobremez, J. F., (1972), "Le Nepal," Ecologie et Phytogeographie. Grenoble.

Dobremez, J. F., (1972), "Les grandes division Phytogeographiques du Nepalet de 1" Himalaya." Bull. Soc. Bot. France 199, 111-120. France.

Dobremez, J. F. \& P. R. Shakya, (1975), "Carte ecologique du Nepal IV region Biratnager-Kanchenjunga" I/25000 Doc. Cart. Ecol. 16, 33-48

Hara, H., 1966, (1971), "The flora of Eastern Himalaya." Univ. Mus. Univ. of Tokyo. Japan.

Hara, H. Stearn.W.T. \& Willams L.H.J., (1978), "Enumeration of Flowering Plants of Nepal." Vol. I, British Museum (Natural History) London.

Hara, H. \& Willams L.H.J., (1979), "Enumeration of Flowering Plants of Nepal." Vol. II, British Museum (Natural History) London.

Hara, H. Chater. A. \& Willams L.H.J., (1982), "Enumeration of Flowering Plants of Nepal." Vol. III, British Museum (Natural History) London.g 
Hooker, J. D. (1827-1897), The Flora of British India. Vol. I to VII, India.

Joshi, et. al., (1975), "Vegetation Zones and slash and burn practice in Nepal Himalaya." Paper presented for UNESCO regional meeting of MAB. Sept 26-Oct 2. Kathamandu. Nepal.

Kanai, H., (1966), "Phytogeography of Eastern Himalaya with reference to the relationship between Himalaya and Japan." The Flora of Eastern Himalaya, Univ. of Tokyo. Japan 13-38. Japan.

Kanai, H. Shakya, P. R. \& T. B. Sherstha, (1975), "Vegetation Survey of Central Nepal . In Ohashi," Flora of Eastern Himalaya. Univ. Mus. Bull. No. 8., Tokyo. Japan.

Kihara, H., (1955), Fauna and Flora of Nepal Himalaya. Vol. I, Japan.

Magnandhar, N. P. (1980), "Contribution a L' etude des Plants Sauvages utiles du Nepal et des Pays Himalayas. These docteur de 3' eme cycle." Univ. Scientifique et medicale de Grenoble, France.

Mani, M. S., (1984-85), "Himalayan Zones and Vegetation." Nepal Nature Paradise, pp. 18-25, White Lotus Co. Bangkok Thailand.

Numata, M., (1969), "Vegetation and Conservation in Eastern Nepal." Jour. collage of Arts and Science. Chiba University. Vol. No 14, 559-569, Japan.

Ohashi, H., (1975), "Flora of Eastern Himalaya. 3rd Report.". Univ, Mus. Univ. of Tokyo. Bull. No.8.

Ohba, H., (1988), "The alpine flora of Nepal Himalaya. An Introductory Note," The Himalaya Plants. Vol. I, 19-46. Tokyo, Japan.

Pandey, B. D., (1970), "Glimpses of the flora of Nepal." The Rising Nepal, Nov. 4. Polunin, O. \& J. D. A. Stainton, (1984), Flowers of Himalaya, Oxford Univ, Press
Delhi.

Rau, M. A., (1974), "Vegetation and Phytogeography of Himalaya," In Mani, M.S. (edt.) Ecology and Biogeography in India (Monographic bilogicae), 247-280.

Shakya, P. R, (1979), "Contribution a la Phytogeographic de L' Himalaya, These de doctorate de 3 eme cycle." University Scientifique et Medicale, Gnenoble, France. 
Sherstha, K., (1984), "A field Guide of Nepali Names for Plants," Natural History Museum, Tribhuvan university, Kathamandu.

Sherstha, T. B., (1977), "Le Nord- ouest de Nepal (region Jumla- Saipal) Recherche ecologiques biogeographiques et cartographiques. These." University Scientifique et medical de, Grenoble, France

Sherstha, T. B., (1982), Ecology and Vegetation of North-West Nepal, Royal Nepal Academy, Kathamandu.

Station, J. D. A., (1972), Forests of Nepal, John Murrey, London.

Stearn, W. T., (1960), "Allium and Milium in Central and Eastern Himalaya." Bull. Br. Mus. Nat. Hist. (Bot), 2, 159-161, London.

Yoda, K., (1967), "A preliminary Survey of forest vegetation of Eastern Nepal." Jour. collage of Arts and Science, Chiba University, Vol.5, No.1, 99-140. 